\title{
PERANCANGAN DAN PEMBUATAN APLIKASI CARIKOST DENGAN METODA SIMPLE ADDITIVE WEIGHTING BERBASIS WEB DAN ANDROID
}

\author{
Yudho Yudhanto \\ Fakultas MIPA, Program Studi D3 Teknik Informatika \\ Universitas Negeri Sebelas Maret \\ Email: yuda@mipa.uns.ac.id \\ Fadlul Ilmi Khairun \\ Fakultas MIPA, Program Studi D3 Teknik Informatika \\ Universitas Negeri Sebelas Maret \\ Email:m3113056@gmail.com \\ Winita Sulandari \\ Fakultas MIPA, Program Studi Statistika \\ Universitas Negeri Sebelas Maret \\ Email:winita@mipa.uns.ac.id
}

\begin{abstract}
ABSTRAK
Rumah kost merupakan tempat tinggal yang disewakan bagi perantau yang menetap diarea tertentu dalam jangka waktu tertentu. Sudah banyak teknologi yang menawarkan tentang informasi kost namun masih dianggap kurang efisien karena untuk mencari kost yang sesuai dengan kriteria yang diinginkan, pencari kost masih harus membandingkan satu persatu fasilitas maupun kriteria-kriteria yang dimiliki kost tersebut. Penggunaan metode Simple Additive Weighting (SAW) pada sebuah sistem pendukung keputusan merupakan salah satu jalan pemecahan masalah yang dapat menangani hal tersebut, dimana pencari kost akan merasa terbantu karena dapat memberikan rekomendasi tempat kost yang sesuai dengan kriteria yang diinginkan.

Metode penelitian yang dilakukan untuk merancang dan membuat aplikasi ini adalah dengan menggunakan metode penelitian waterfall yaitu dengan pengumpulan data, melakukan analisa sistem (menentukan kebutuhan fungsional dan non fungsional), melakukan perancangan (ERD, use case diagram, use case text, sequence diagram, dan class diagram), dan implementasi (coding dan testing). Sistem informasi marketplace ini dibuat menggunakan bahasa pemrograman PHP berbasis framework Codeigniter 2 dan basis data MySQL.

Aplikasi yang difokuskan dalam mencari rekomendasi kost yang sesuai dengan kriteria yang sesuai sampai dengan pemesanan untuk kamar kost tersebut dapat dilakukan dengan aplikasi ini. Dengan adanya Aplikasi ini diharapkan dapat membantu para pencari kost untuk mendapatkan rekomendasi kost terbaik dan dapat membantu dalam pemesanan kamar kost serta memberikan keuntungan terhadap pemilik kost untuk dapat memasarkan rumah kost nya.
\end{abstract}

Kata kunci : Codeigniter, Rumah Kost, Sistem Pendukung Keputusan (SPK), PHP, Simple Additive Weighting (SAW).

\section{ABSTRACT}

Boarding house is a residence for rent for certain immigrants who settled diarea within a certain period. There have been many technologies that offer information about the boarding house but is still considered to be less efficient due to search for boarding in accordance with the desired criteria, boarding seekers still have to compare one by one facility as well as the criteria that owned the boarding house. Use of Simple Additive weighting method ( SAW) on a decision 
support system is one of the solutions to deal with such matters, where the boarding seekers will find it helpful because it can give recommendations boarding places corresponding to the desired criteria .

Research methodology to design and create this application is to use research methods waterfall that is by collecting data, analyzing system (define functional requirements and non functional), do the design (ERD, use case diagrams, use case text, sequence diagrams, and class diagram), and implementation (coding and testing). Marketplace information system is created using the programming language PHP CodeIgniter-based framework 2 and the MYSQL database.

Applications are focused in finding a boarding recommendation in accordance with the criteria corresponding to the booking to boarding room can be done with this application. With the app is expected to help seekers boarding house to get the best boarding recommendation and can assist in the boarding room reservations and provide benefits to the owner of the boarding house to be able to market his boarding house .

Keywords : Codeigniter, Boarding house, Decision Support System (DSS), PHP, Simple Additive Weighting $(S A W)$.

\section{PENDAHULUAN}

Kost merupakan tempat tinggal yang disewakan bagi perantau yang menetap diarea tertentu dalam jangka waktu tertentu. Jumlah kos-kosan di Kota Solo saat ini diakui memang sudah sangat banyak. Di wilayah Kelurahan Jebres saja, hingga akhir 2012 tercatat ada sebanyak 766 rumah kos ${ }^{[1] .}$

Banyaknya kost-kost yang terdapat di kota Solo menyebabkan calon penghuni kost terutama mahasiswa mengalami kesulitan dalam mencari tempat kost terlebih bagi mahasiswa yang domisilinya jauh. Walaupun sudah banyak teknologi yang menawarkan tentang informasi kost namun masih dianggap kurang efisien karena sistem yang berjalan masih menggunakan teknologi konvensional yaitu masih membandingkan satu persatu fasilitas maupun kriteria-kriteria yang dimiliki kost tersebut.

Masalah lainnya adalah untuk melakukan pemesanan kost-an, biasanya pemesan melakukan pemesanan secara langsung ataupun melalui telpon. Namun tidak semua calon penghuni kos punya kesempatan untuk memesan kos kos-an sejak jauh jauh hari. Sehingga ada calon penghuni kos kosan yang terpaksa harus menyewa kos yang letaknya jauh dari kampus ataupun lokasi tujuan.

Sebelum mencari dan memberikan solusi atas permasalahan yang ada. Maka studi pustaka kami lakukan dalam perancangan dan pembuatan aplikasi Cari Kost, penulis mengambil dua penelitian. Penelitian tersebut ditulis oleh Uliana Permata $\mathrm{S}$ dengan judul "Pemanfaatan Metode Simple Additive Wighting (SAW) untuk Pemilihan Hotel" "2] dan artikel kedua ditulis oleh Arya Maulana Nugroho, Asep Mulyana dan Tody Ariefianto Wibowo dengan judul "Sistem Informasi Dan Pemesanan Kos Berbasis Sistem Operasi Android". ${ }^{3]}$

Penelitian telah dilakukan oleh Uliana Permata S, Universitas Pendidikan Indonesia pada tahun 2012 dengan studi "Pemanfaatan Metode Simple Additive Wighting (SAW) untuk Pemilihan Hotel ". Dalam penelitian ini sistem yang dibuat mampu menentukan pemilihan hotel yang paling terbaik di sekitar Kota Bandung berdasarkan kriteria-kriteria tertentu seperti harga, fasilitas, lokasi, pelayanan staf, keamanan dan kebersihan dengan menggunakan metode Simple Additive Wighting.

Penelitian telah dilakukan oleh Arya Maulana Nugroho, Asep Mulyana, Tody Ariefianto Wibowo, Univeristas Telkom pada tahun 2012 dengan studi "Sistem Informasi Dan Pemesanan Kos Berbasis Sistem Operasi Android”. Dalam penelitian ini sistem yang dibuat mampu memberikan informasi berita, public spot serta kos-kosan, mampu melakukan pemesanan kost dan dapat men-Tracking keberadaan kos-an di sekitar IT Telkom.

Adanya permasalahan tersebut, maka diperlukan perancangan sistem yang dapat mendukung dalam mengambil suatu keputusan dalam membantu pemilihan tempat kost di Kota Solo dan dapat melakukan pemesanan secara cepat dan mudah. Dalam penelitian ini, penulis menggunakan metode Simple Additive Weighting $(S A W)$. Metode SAW ini dipilih karena metode ini menentukan nilai bobot untuk setiap atribut, kemudian dilanjutkan dengan proses perankingan yang akan menyeleksi alternatif terbaik dari sejumlah alternatif, dalam hal ini alternatif yang dimaksud adalah kost yang memiliki kriteria sesuai dengan yang diinginkan calon pengunjung. 


\section{METODOLOGI PENELITIAN}

Metodologi penelitian yang digunakan untuk menyelesaikan penelitian ini adalah waterfall models. ${ }^{[4]}$. Alur yang dilakukan adalah seperti gambar 1 berikut ini :

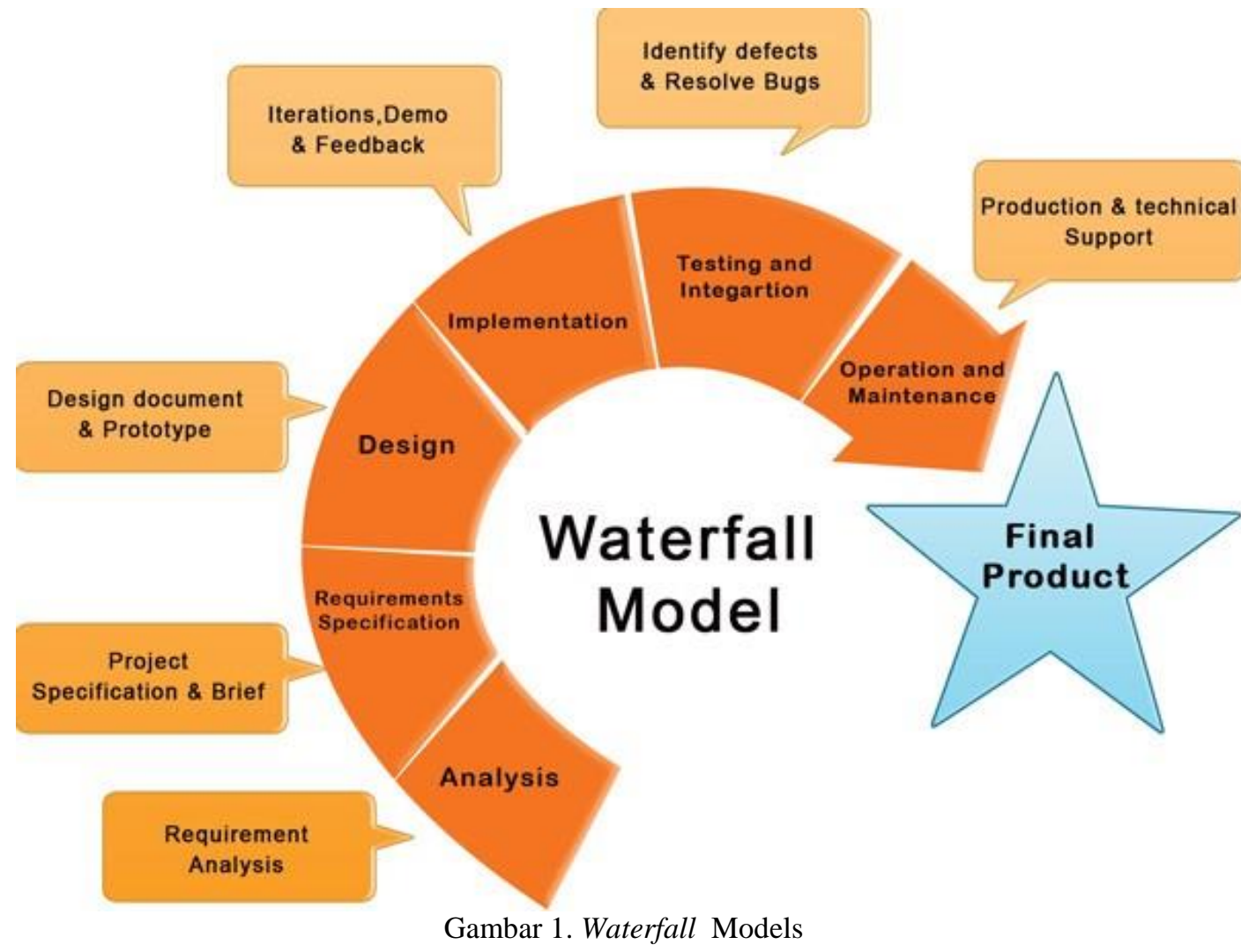

Kemudian untuk detail pelaksanaannya dibagai dalam beberapa tahap yakni seperti berikut :

\subsection{Tahap persiapan}

Pada tahap ini dilakukan kajuan literatur seperti perumusan masalah dan penentuan tujuan penelitian.

\subsection{Tahap Analisis}

Pada tahap ini dilakukan analisis kebutuhan pengguna maupun sistem melalui survei lapangan aplikasi penyedia informasi kost yang sudah ada.

\subsection{Tahap perancangan}

Pada tahap ini dilakukan perancangan struktur basisdata dan kebutuhan fungsionalitas sistem. 


\subsection{Tahap Implementasi}

Pada tahap ini dilakukan implementasi aplikasi pada bagian database, front end, back end.

Sistem yang dikembangkan dalam bentuk website dan mobile android.

\subsection{Tahap pengujian}

Pada tahap ini dilakukan pengujian desain dan pengujian fungsional yang bertujuan untuk menguji apakah implementasi sistem sudah sesuai dengan rancangan dan model sistem serta untuk menguji apakah sistem yang dikembangkan melakukan fungsi fungsi yang bersesuaian dengan tujuan.

\subsection{Tahap pelaporan}

Tahap ini adalah tahap akhir yang terdiri dari kesimpulan, saran saran, perbaikan dan pengembangan sistem serta penulisan laporan.

\section{HASIL DAN PEMBAHASAN}

\subsection{Proses Bisnis Aplikasi}

Berikut adalah gambaran umum proses bisnis yang akan dibuat dalam aplikasi Cari Kost, dapat dilihat pada Gambar 2

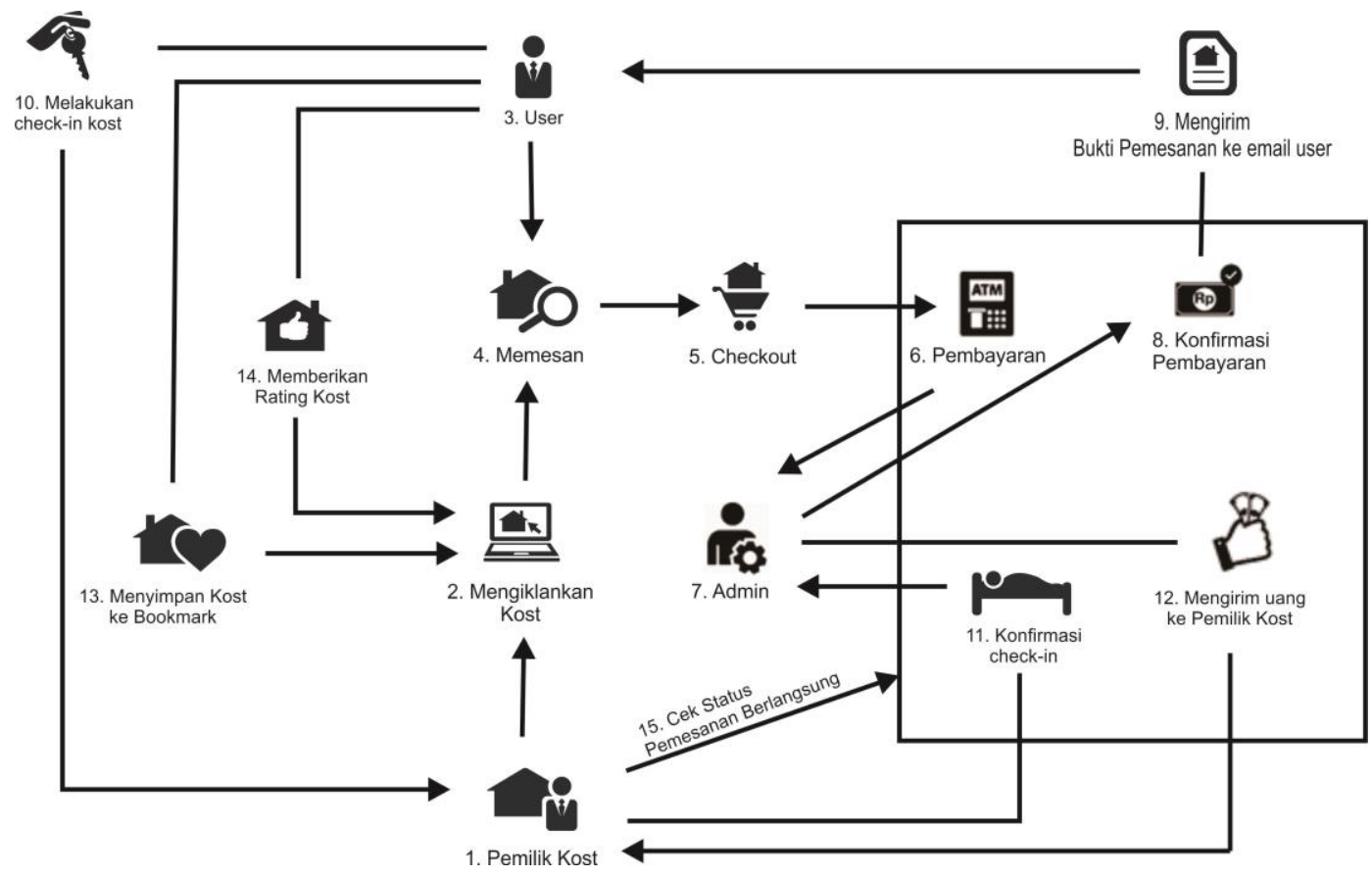

Gambar 2. Proses bisnis Aplikasi

Dari gambar tersebut menunjukkan bahwa aplikasi ini digunakan untuk menjembatani antara Pemilik kost dan User (Pemesan) dalam melakukan transaksi pemesanan kamar kost.

Dalam penyeleksian penentuan kost yang sesuai dengan kriteria yang diinginkan ini akan menggunakan metode Fuzzy Multiple Attribute Decision Making (FMADM) dengan metode 
Simple Additive Weighting (SAW) diperlukan kriteria-kriteria dan bobot untuk melakukan perhitungannya sehingga akan didapat alternative terbaik.

Kriteria yang dibutuhkan dalam metode penelitian ini ada beberapa kriteria yang dibutuhkan untuk pengambilan keputusan menentukan kost yang sesuai dengan kriteria. Adapun kriterianya yang telah ditentukan yaitu :

1. Harga Sewa Kost (C1)

2. Fasilitas Kost $(\mathrm{C} 2)$

3. Akses Area (C3)

4. Jumlah Kamar Kost (C4)

5. Rating Kost (C5)

6. Surat Izin Kost (C6)

Dari kriteria tersebut, maka dibuat suatu tingkat kepentingan kriteria berdasarkan nilai terbobot yang telah ditentukan kedalam bilangan fuzzy. Rating kecocokan setiap alternative (penilai) pada setiap kriteria sebagai berikut :

1. Kurang Sekali / Sangat Mahal $=1$

2. Kurang / Mahal $=2$

3. Cukup / Sedang $=3$

4. Baik / Murah $=4$

5. Baik Sekali / Murah Sekali $=5$

Dari masing-masing bobot tersebut, maka dibuat suatu variabel yang akan dikonversikan ke dalam bilangan fuzzy

\subsection{Use Case}

Use Case Diagram atau diagram use case merupakan pemodelan untuk menggambarkan kelakuan (behavior) sistem yang akan dibuat. Diagram use case mendeskripsikan sebuah interaksi antara satu atau lebih aktor dengan sistem yang akan dibuat. ${ }^{[5]}$

Use Case Diagram aplikasi berbasis web terdiri dari 3 aktor. Aktor yang pertama adalah pengunjung atau guest dan aktor kedua adalah user register atau member . Dan aktor terakhir adalah Admin. Gambar Use Case dapat dilihat pada gambar dibawah ini : 


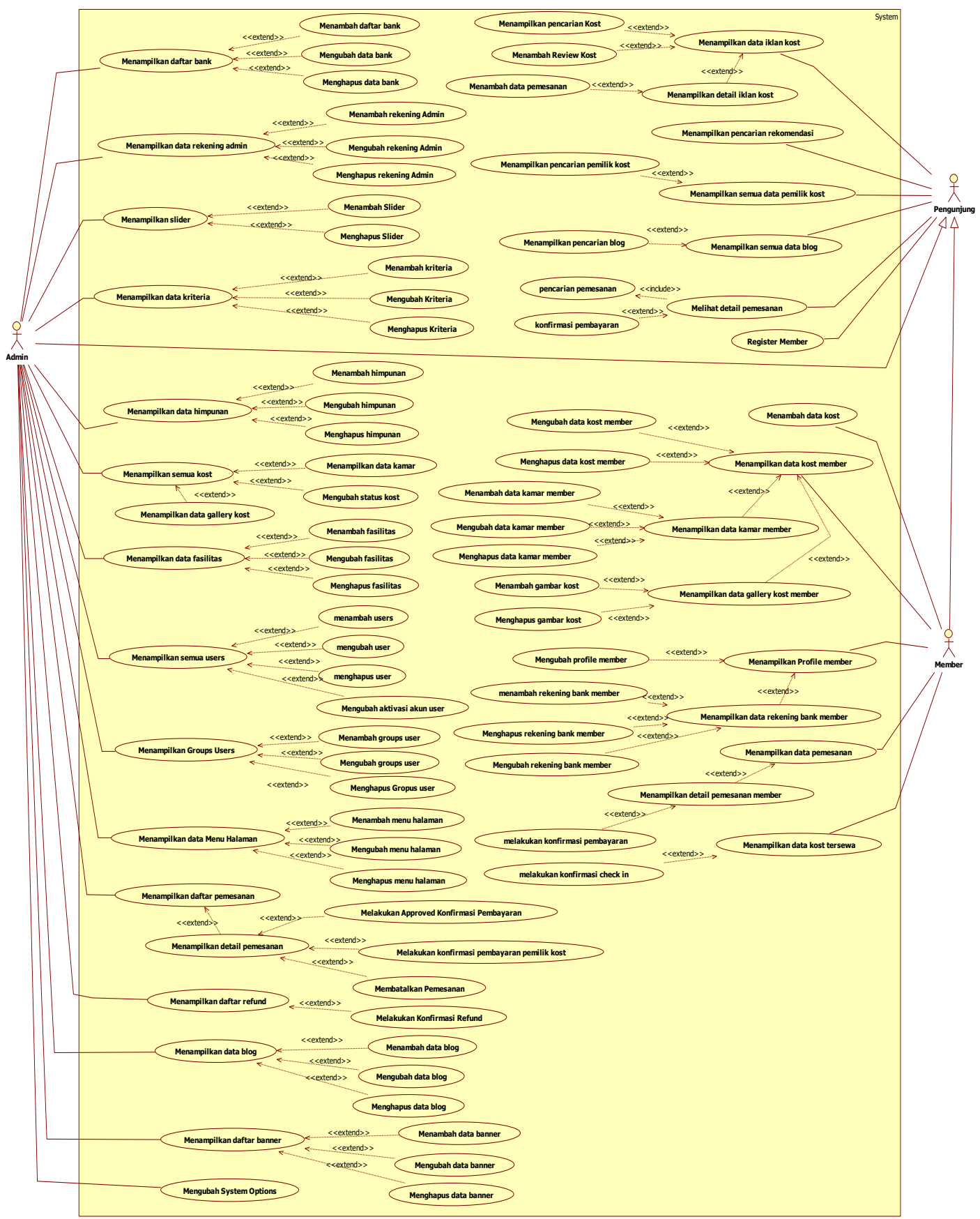

\section{Gambar 3. Use Case}

\subsection{ERD}

Pada rancangan gambar ERD berikut ini akan dapat menghasilkan database Sistem yang akan dibuat 


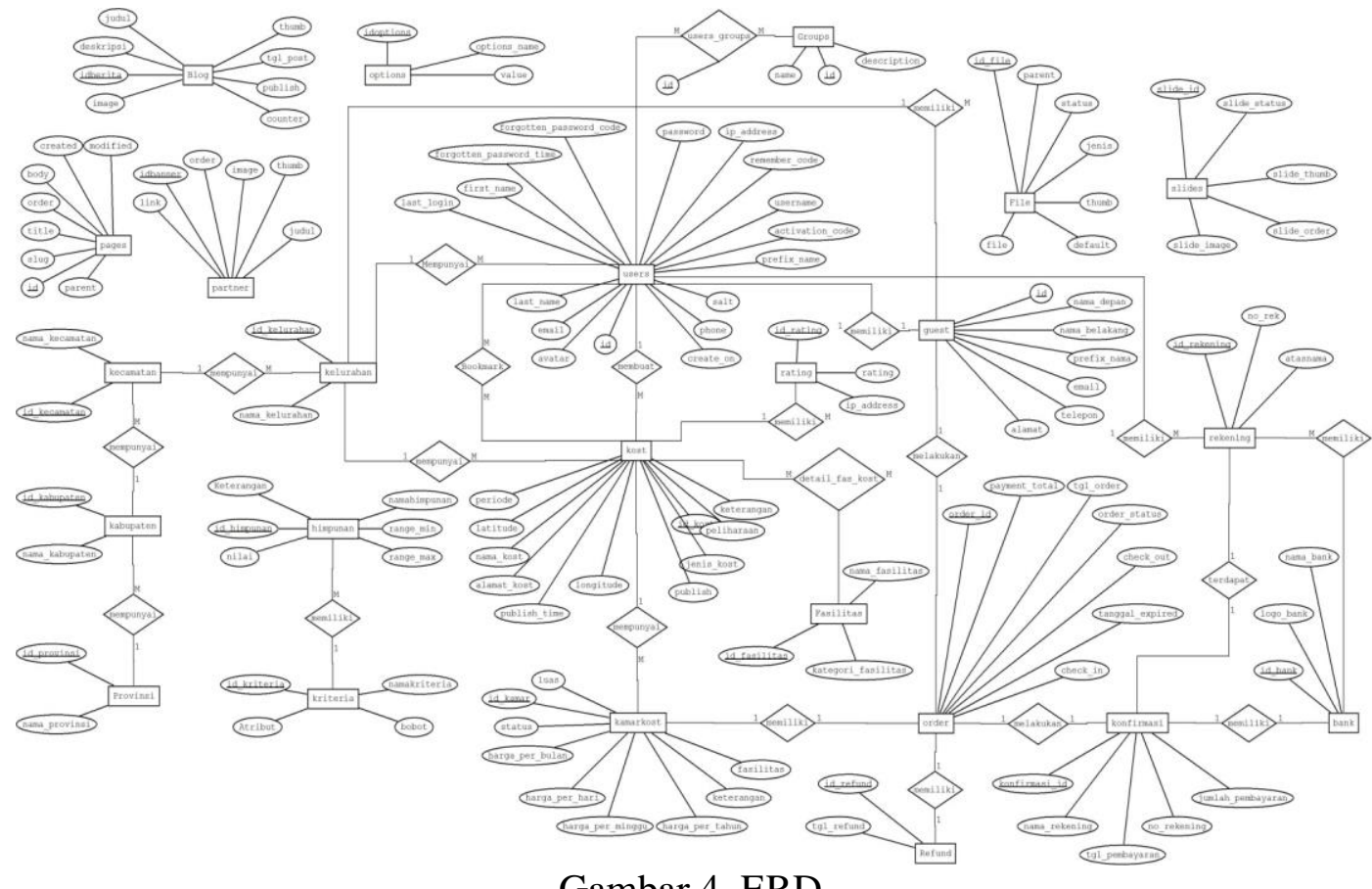

Gambar 4. ERD

\subsection{Relasi Tabel}

Dari gambar ERD yang dibuat maka dihasilkan 29 tabel untuk memenuhi kebutuhan sistem yang akan dibuat.

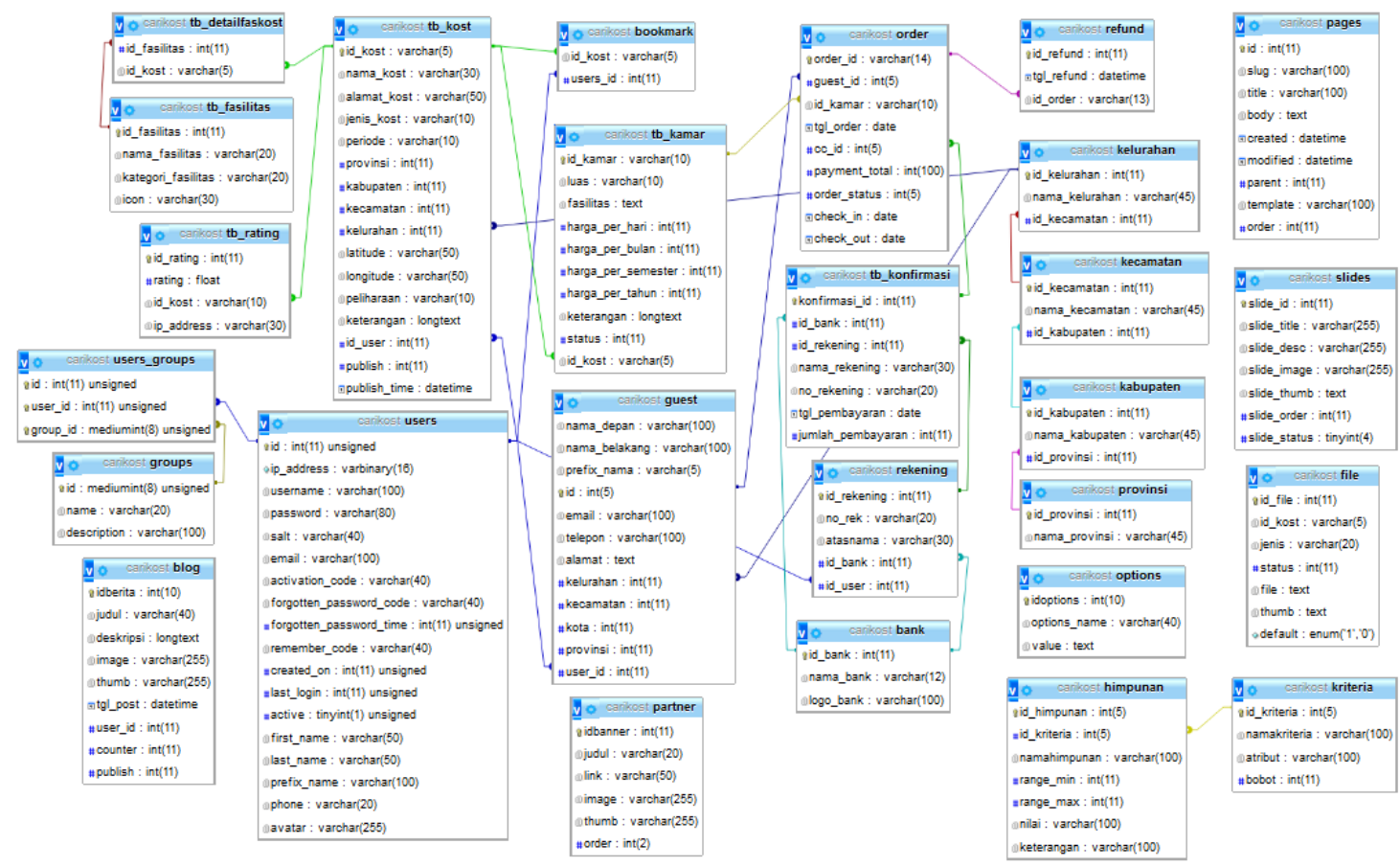

Gambar 5. Mapping Tabel 
Indonesian Journal of Applied Informatics, Vol.1 No. 1 November 2016

ISSN: 2548-3846

\subsection{Desain User Interface}

Berikut ini adalah beberapa rancangan user interface yang akan dibuat, diantaranya adalah :

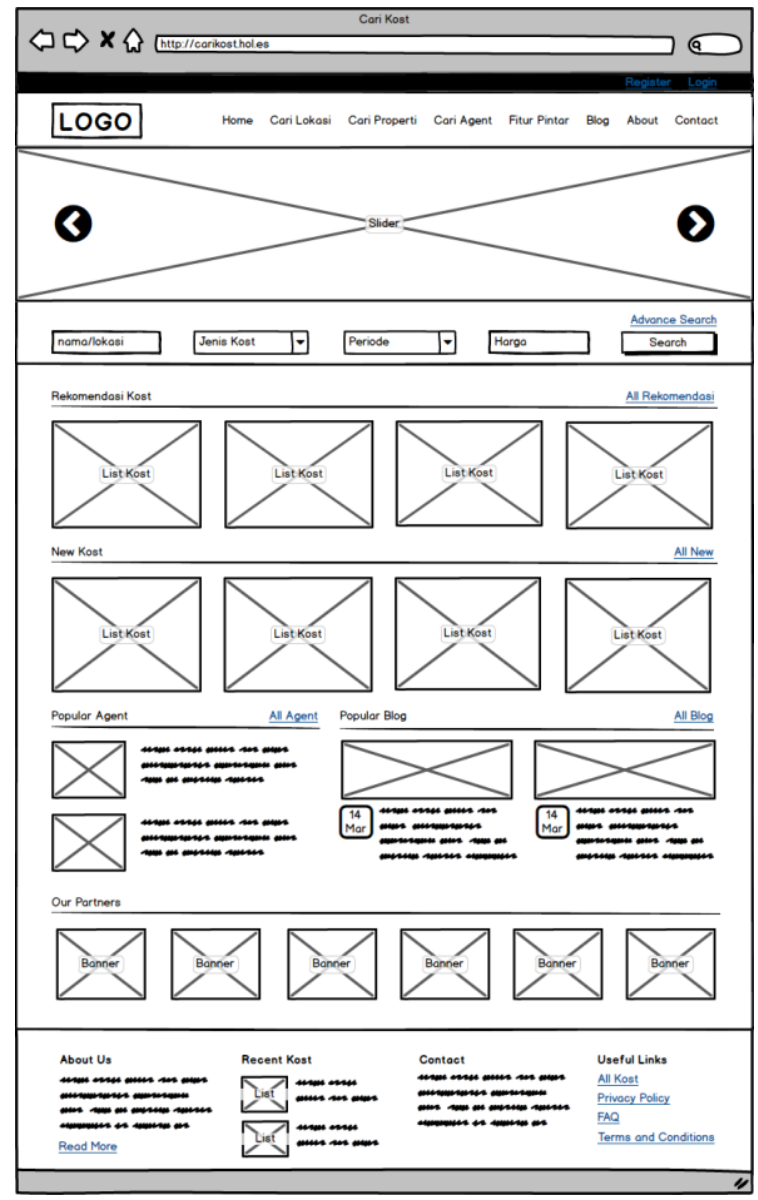

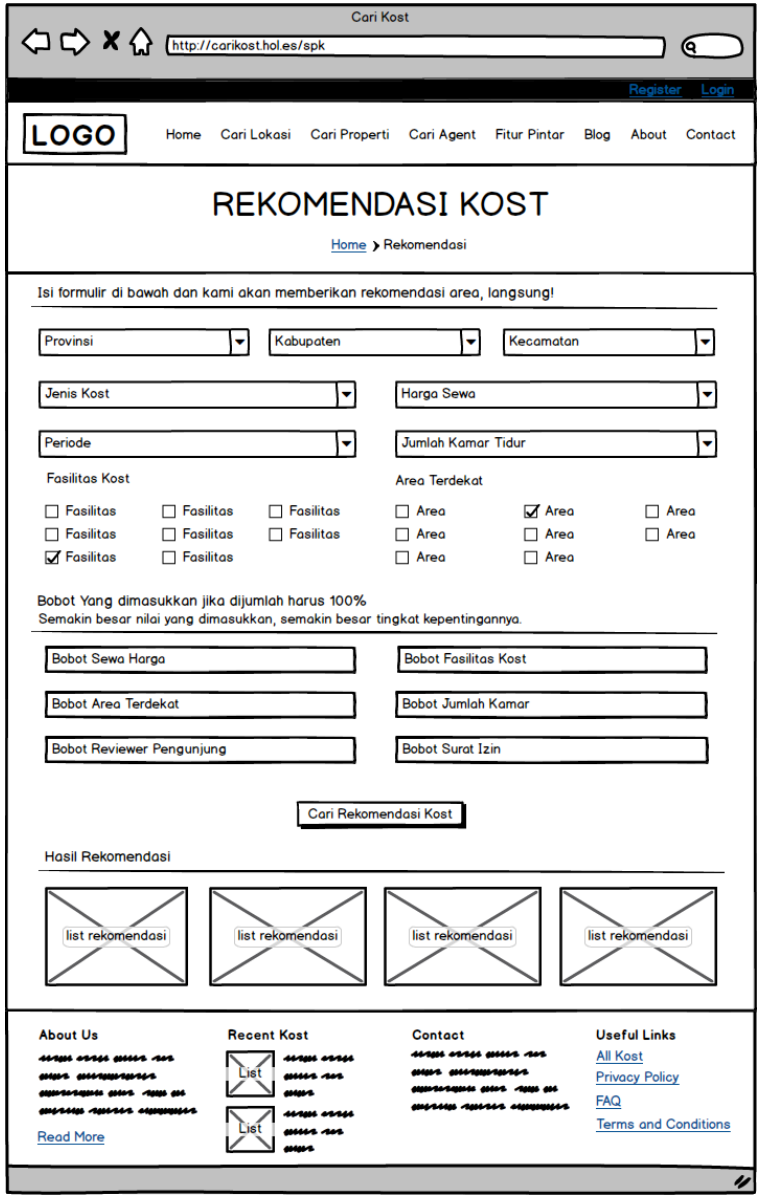

Gambar 6. Rancangan UI untuk Home dan Halaman Rekomendasi 


\begin{tabular}{|c|c|c|}
\hline \multicolumn{3}{|c|}{ Cari Kost } \\
\hline CARI KOST ADMIN & & $\underline{\text { Visit Site }} \underline{\text { Logout }}$ \\
\hline Dasboard & \multirow{3}{*}{$\begin{array}{l}\text { Menampilkan Data } \\
\text { Drag \& Drop }\end{array}$} & \\
\hline Daftar Kost & & \\
\hline Daftar Fasilitas & & \\
\hline Data Order & Data 1 & Aksi \\
\hline Daftar Bank & \multirow{2}{*}{ Data 2} & \\
\hline Daftar Rekening & & \\
\hline Daftar User & \multirow[t]{2}{*}{ Data 3} & Aksi \\
\hline Daftar Halaman & & \\
\hline Daftar Slider & Data 4 & Aksi \\
\hline Daftar Banner & \multirow{2}{*}{ Save } & \\
\hline System Options & & \\
\hline
\end{tabular}

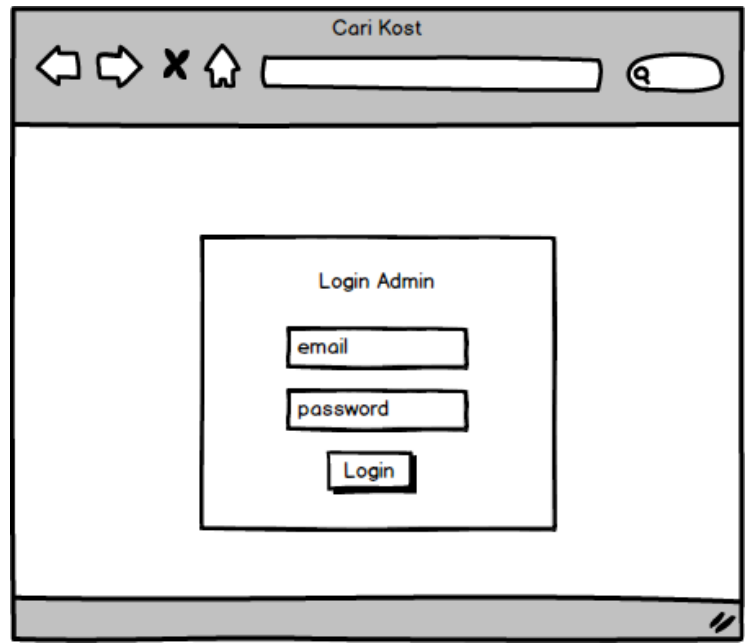

Gambar 7. Rancangan UI untuk Tampil data dan Login

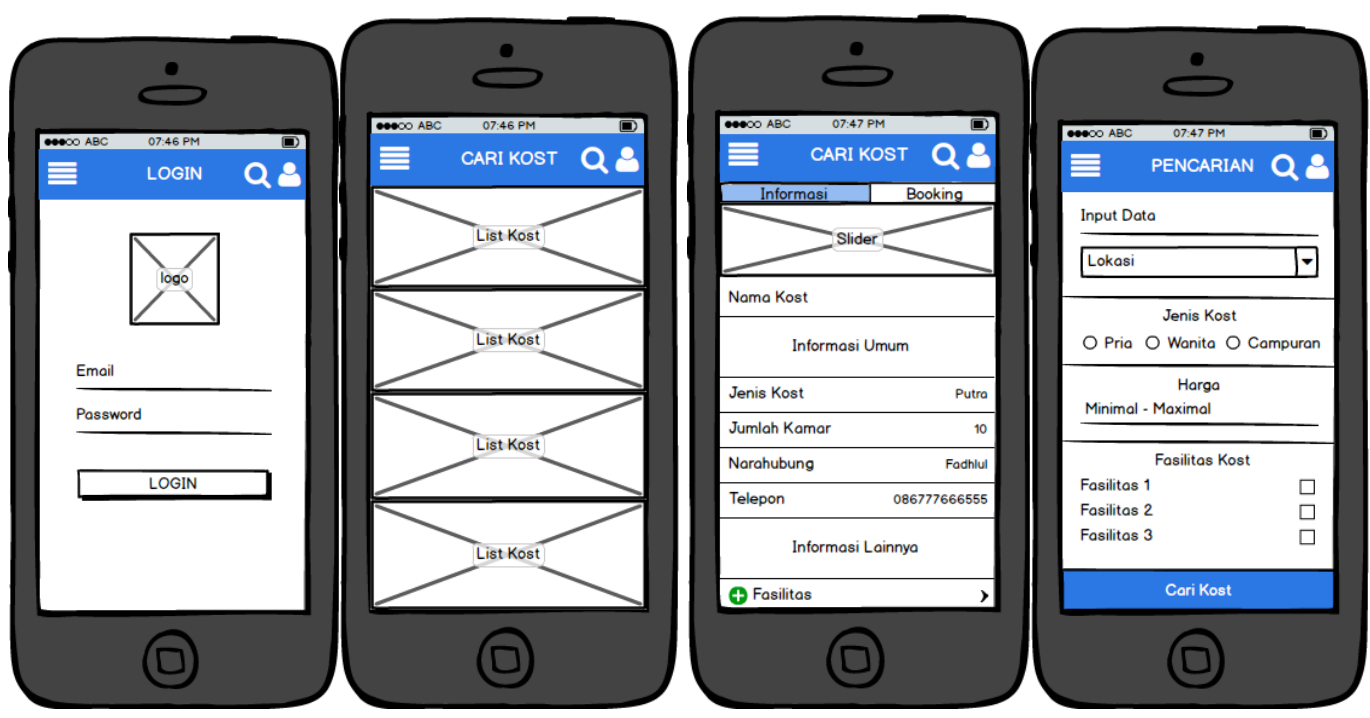

Gambar 8. Rancangan UI untuk Aplikasi Mobile 
Indonesian Journal of Applied Informatics, Vol.1 No. 1 November 2016

ISSN: 2548-3846

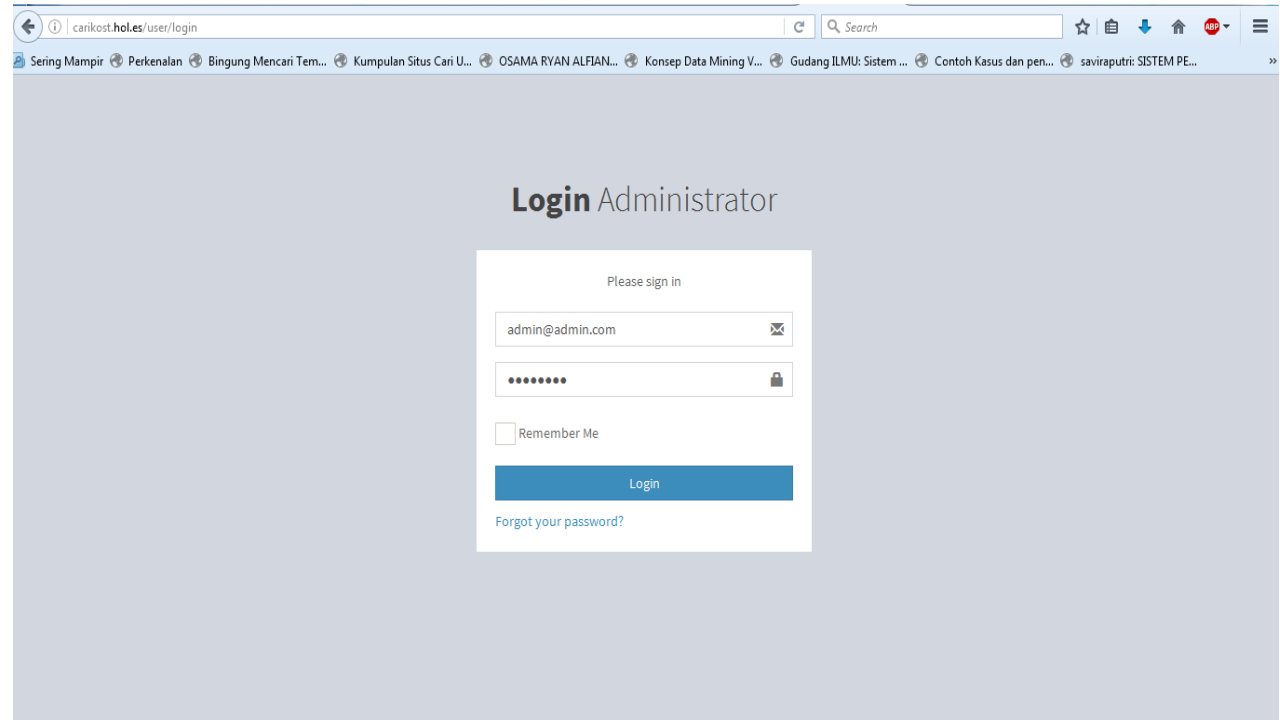

Gambar 9. Implementasi desain Login

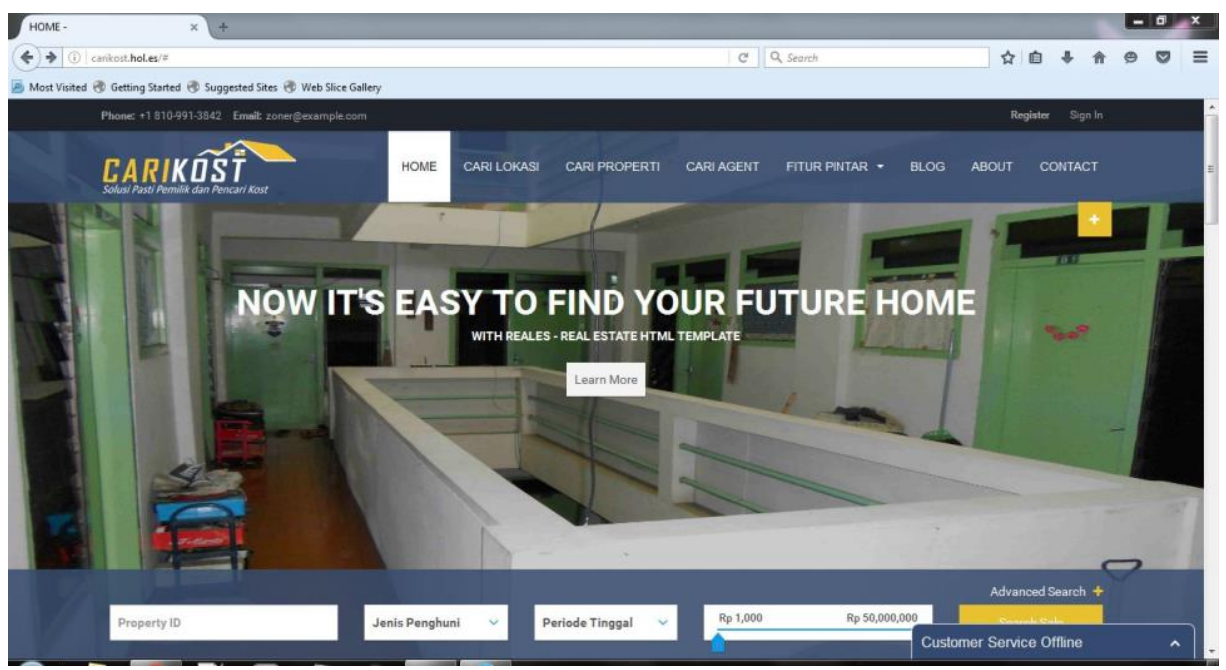

Gambar 10. Implementasi desain halaman home 

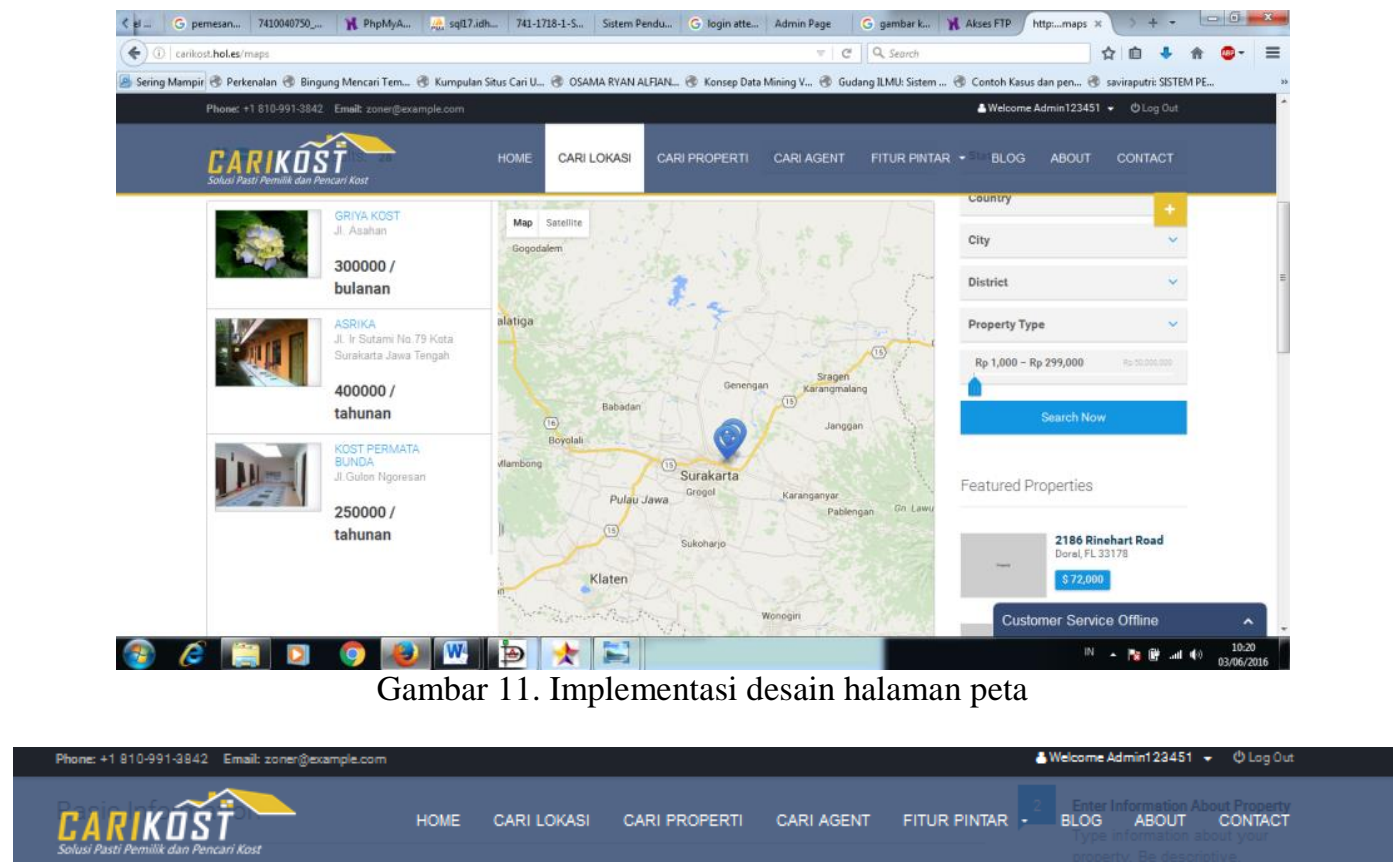

Nama Kost

Deacription

Jenis Kost

- Piilh Jenis Kost -

Periode

Bulanan

Peliharaan

(-) Boleh Tidak Boleh

Address

Place on Map

Get My Position 9

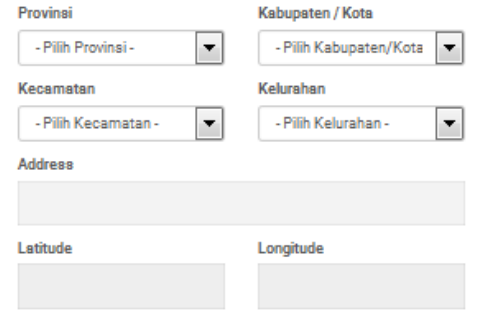

$\square$ Allow user rating 0

Gambar 12. Implementasi desain halaman pencarian 

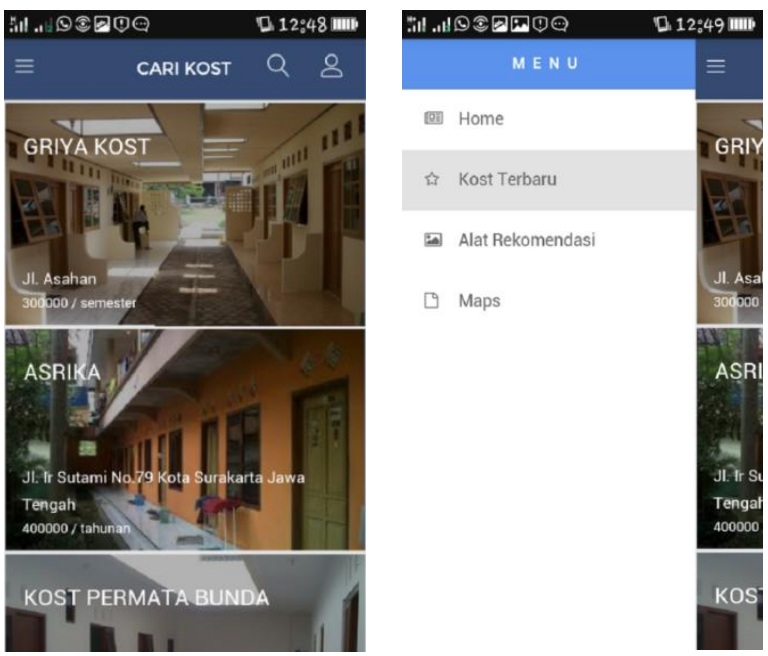

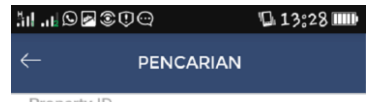

Property ID

- Pilih Provinsi -

- Pilih Kabupaten/Kota -

- Periode Tinggal -

JENIS KOST

Putra $\bigcirc$ Putri $\bigcirc$ campuran

KISARAN HARGA

Harga Mini ‘ Harga Ma:

FASILITAS KOST

WI-FI

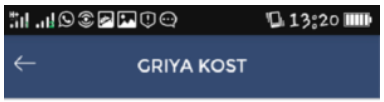

Booking
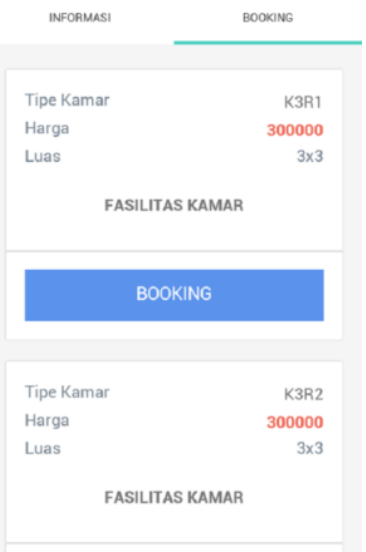

Gambar 13. Implementasi desain halaman Android

\subsection{Pengujian}

Dalam penelitian ini akan dicontohkan satu perhitungan untuk mencari tempat kost dari 4 kost yang menjadi alternatif. Pengambilan keputusan memberikan bobot preferensi yang sudah ditentukan sebelumnya yaitu:

$$
W=[0.25,0.2,0.2,0.15,0.1,0.1]
$$

Langkah Penyelesaian sebagai berikut :

1. Membuat tabel rating kecocokan dari setiap alternatif pada setiap kriteria

\section{Tabel 1 Rating Kecocokan dari setiap alternative pada setiap kriteria}

\section{Alternatif Kriteria}

\begin{tabular}{llllll}
\hline$C 1$ & $C 2$ & $C 3$ & $C 4$ & $C 5$ & $C 6$
\end{tabular}

\begin{tabular}{ccccccc}
\hline Kost $A$ & 4 & 3 & 4 & 2 & 5 & 1 \\
\hline Kost $B$ & 4 & 4 & 5 & 3 & 3 & 2 \\
\hline Kost $C$ & 3 & 2 & 6 & 3 & 4 & 1 \\
\hline Kost $D$ & 3 & 5 & 4 & 4 & 4 & 1
\end{tabular}

2. Membuat matrik keputusan $X$ yang dibentuk dari tabel rating kecocokan dari setiap alternatif pada setiap kriteria.

Dari Tabel diubah kedalam matrik keputusan X dengan Data:

$$
X=\left(\begin{array}{llllll}
4 & 2 & 4 & 2 & 5 & 1 \\
4 & 4 & 5 & a & a & 2 \\
9 & 2 & 6 & a & 4 & 1 \\
9 & 5 & 4 & 4 & 4 & 1
\end{array}\right)
$$


3. Melakukan Normalisasi matrik keputusan $\mathrm{X}$ dengan cara menghitung nilai rating kinerja ternormalisasi ( $\mathrm{r}_{\mathrm{ij}}$ ) dari alternatif $\mathrm{A}_{\mathrm{i}}$ pada kriteria $\mathrm{C}_{\mathrm{i}}$

$$
r_{i j}= \begin{cases}\frac{x_{i j}}{\operatorname{Max}_{i}\left(x_{i j}\right)} & \text { Jika j adalah kriteria keuntungan (benefit) } \\ \frac{\operatorname{Min}_{i}\left(x_{i j}\right)}{x_{i j}} & \text { Jika j adalah kriteria biaya (cost) }\end{cases}
$$

Karena setiap nilai yang diberikan pada setiap alternatif di setiap kriteria merupakan nilai kecocokan(nilai terbesar adalah terbaik) maka semua kriteria yang diberikan diasumsikan sebagai kriteria keuntungan. Pertama-tama, dilakukan normalisasi matrik X berdasarkan pada persamaan (1) sebagai berikut:

a. Untuk Harga Sewa Kamar Kost

$$
\begin{aligned}
& \mathrm{r}_{11}=\frac{4}{\operatorname{Max}\{4,4,3,3\}}=\frac{4}{4}=1 \\
& \mathrm{r}_{21}=\frac{4}{\operatorname{Max}\{4,4,3,3\}}=\frac{4}{4}=1 \\
& \mathrm{r}_{31}=\frac{3}{\operatorname{Max}\{4,4,3,3\}}=\frac{3}{4}=0,75 \\
& \mathrm{r}_{41}=\frac{3}{\operatorname{Max}\{4,4,3,3\}}=\frac{3}{4}=0,75
\end{aligned}
$$

b. Untuk Fasilitas Kost

$$
\begin{aligned}
& \mathrm{r}_{12}=\frac{3}{\operatorname{Max}\{3,4,2,5\}}=\frac{3}{5}=0,6 \\
& \mathrm{r}_{22}=\frac{4}{\operatorname{Max}\{3,4,2,5\}}=\frac{4}{5}=0,8 \\
& \mathrm{r}_{32}=\frac{3}{\operatorname{Max}\{3,4,2,5\}}=\frac{2}{5}=0,4 \\
& \mathrm{r}_{42}=\frac{3}{\operatorname{Max}\{3,4,2,5\}}=\frac{5}{5}=1
\end{aligned}
$$

c. Untuk Akses Area Kost

$$
\begin{aligned}
& r_{11}=\frac{4}{\operatorname{Max}\{4,5,6,4\}}=\frac{4}{6}=0,67 \\
& r_{21}=\frac{5}{\operatorname{Max}\{4,5,6,4\}}=\frac{5}{6}=0,83
\end{aligned}
$$




$$
\begin{aligned}
& \mathrm{r}_{31}=\frac{6}{\operatorname{Max}\{4,5,6,4\}}=\frac{6}{6}=1 \\
& \mathrm{r}_{41}=\frac{4}{\operatorname{Max}\{4,5,6,4\}}=\frac{4}{6}=0,67
\end{aligned}
$$

d. Untuk Jumlah Kamar Kost

$$
\begin{aligned}
& \mathrm{r}_{11}=\frac{2}{\operatorname{Max}\{2,3,3,4\}}=\frac{2}{4}=0,5 \\
& \mathrm{r}_{21}=\frac{3}{\operatorname{Max}\{2,3,3,4\}}=\frac{3}{4}=0,75 \\
& \mathrm{r}_{31}=\frac{3}{\operatorname{Max}\{2,3,3,4\}}=\frac{3}{4}=0,75 \\
& \mathrm{r}_{41}=\frac{4}{\operatorname{Max}\{2,3,3,4\}}=\frac{4}{4}=1
\end{aligned}
$$

e. Untuk Rating Kost

$$
\begin{aligned}
& \mathrm{r}_{11}=\frac{5}{\operatorname{Max}\{5,3,4,4\}}=\frac{5}{5}=1 \\
& \mathrm{r}_{21}=\frac{3}{\operatorname{Max}[5,3,4,4\}}=\frac{3}{5}=0,6 \\
& \mathrm{r}_{31}=\frac{4}{\operatorname{Max}[5,3,4,4]}=\frac{4}{5}=0,8 \\
& \mathrm{r}_{41}=\frac{4}{\operatorname{Max}[5,3,4,4\}}=\frac{4}{5}=0,8
\end{aligned}
$$

f. Untuk Surat Izin Kost

$$
\begin{aligned}
& \mathrm{r}_{11}=\frac{1}{\operatorname{Max}\{1,2,1,1\}}=\frac{1}{2}=0,5 \\
& \mathrm{r}_{21}=\frac{2}{\operatorname{Max}\{1,2,1,1\}}=\frac{2}{2}=1 \\
& \mathrm{r}_{31}=\frac{1}{\operatorname{Max}\{1,2,1,1\}}=\frac{1}{2}=0,5
\end{aligned}
$$




$$
\mathrm{r}_{41}=\frac{1}{\operatorname{Max}\{1,2,1,1\}}=\frac{1}{2}=0,5
$$

4. Hasil dari nilai rating kinerja ternormalisasi (rij) membentuk matrik ternormalisasi (R)

$$
\mathrm{X}=\left(\begin{array}{cccccc}
1 & 0,6 & 0,67 & 0,5 & 1 & 0,5 \\
1 & 0,9 & 0,98 & 0,75 & 0,6 & 1 \\
0,75 & 0,4 & 1 & 0,75 & 0,9 & 0,5 \\
0,75 & 1 & 0,67 & 1 & 0,9 & 0,5
\end{array}\right)
$$

5. Melakukan proses perangkingan dengan menggunakan persamaan(2):

$$
V_{i}=\sum_{j=1}^{n} w_{j} r_{i j}
$$

Jadi :

$$
\begin{aligned}
\mathrm{V}_{1}= & (0,25)(1)+(0,2)(0,6)+(0,2)(0,67)+(0,15)(0,5)+(0,1)(1) \\
& +(0,1)(0,5) \\
= & 0,25+0,12+0,134+0,075+0,1+0,05 \\
= & 0,729 \\
V_{2}= & (0,25)(1)+(0,2)(0,8)+(0,2)(0,83)+(0,15)(0,75)+(0,1)(0,6) \\
& +(0,1)(1) \\
= & 0,25+0,16+0,166+0,1125+0,06+0,1 \\
= & 0,8485 \\
V_{3}= & (0,25)(0,75)+(0,2)(0,4)+(0,2)(1)+(0,15)(0,75)+(0,1)(0,8) \\
& +(0,1)(0,5) \\
= & 0,1875+0,08+0,2+0,1125+0,08+0,05 \\
= & 0,71 \\
V_{4}= & (0,25)(0,75)+(0,2)(1)+(0,2)(0,67)+(0,15)(1)+(0,1)(0,8) \\
& +(0,1)(0,5) \\
= & 0,1875+0,2+0,134+0,15+0,08+0,05 \\
= & 0,8015
\end{aligned}
$$

Hasil perhitungan nilai Vi yang lebih besar mengindikasikan bahwa alternatif Ai merupakan alternatif terbaik. Hasil penilaian terbesar ada pada Vi yaitu Kost B sehingga kost B layak atau dapat dijadikan alternatif dalam pemilihan hotel sebagai alternatif yang terpilih sebagai alternatif terbaik. Untuk lebih jelas lihat pada tabel

\section{Tabel 2 Rangking Hasil SPK}

\begin{tabular}{cccccccc}
\hline Nama & Harga & Fasilitas & Akses & Jumlah & Rating & Surat & Hasil \\
Kost & Sewa & Kost & Area & Kamar & Kost & Izin & Akhir \\
\hline Kost $B$ & 0,25 & 0,16 & 0,166 & 0,1125 & 0,06 & 0,1 & 0,8485 \\
\hline Kost $D$ & 0,1875 & 0,2 & 0,134 & 0,15 & 0,08 & 0,05 & 0,8015 \\
\hline Kost $A$ & 0,25 & 0,12 & 0,134 & 0,075 & 0,1 & 0,05 & 0,729 \\
\hline Kost $C$ & 0,1875 & 0,08 & 0,2 & 0,1125 & 0,08 & 0,05 & 0,71 \\
\hline
\end{tabular}




\section{KESIMPULAN}

Penelitian yang dilakukan menghasilkan kesimpulan bahwa telah berhasil dilakukan perancangan dan pembuatan Aplikasi Cari Kost berbasis web dan android dengan menggunakan bahasa pemrograman PHP dengan framework Codeigniter dan database MySQL serta menggunakan PhoneGap sebagai Hybrid Application dan pengujian telah berhasil dilakukan dengan metode pengujian blackbox.

\section{DAFTAR PUSTAKA}

[1] Setiyanto, Arif, 2014. Dilema Rumah Kos di Solo Jumlah Ratusan, Minim Pemasukan. di akses 10 Juni 2016, < http://dok.joglosemar.co/baca/2014/08/18/dilema-rumah-kos-di-solojumlah-ratusan-minim-pemasukan.html >

[2] Uliana Permata S,"Pemanfaatan Metode Simple Additive Wighting (SAW) untuk Pemilihan Hotel",2012, UPI

[3] Arya Maulana Nugroho, Asep Mulyana dan Tody Ariefianto Wibowo, "Sistem Informasi Dan Pemesanan Kos Berbasis Sistem Operasi Android", 2012, Telkom University

[4] Pressman, R.S. 2010. Software Engineering: a practitioner's approach. New York: McGraw-Hill.

[5] Abdul Kadir. 2009. Pengenalan Sistem Informasi. Yogyakarta: Andi. 